\title{
Offshoring and the Skill Structure of Labour Demand in Belgium
}

\section{Bart Hertveldt and Bernhard Michel}

A major concern regarding the consequences of offshoring is the worsening of the labour market position of low-skilled workers. This paper addresses this issue by providing evidence on the impact of offshoring on the skill structure of manufacturing employment in Belgium between 1995 and 2007. Offshoring is found to significantly lower the employment share of low-skilled workers. Its contribution to the fall in the employment share of low-skilled workers amounts to $35 \%$. This is mainly driven by offshoring to Central and Eastern European countries. Moreover, our analysis contains three extensions with respect to the existing literature. First, while previous papers exclusively focus on materials offshoring, we show that offshoring of business services also contributes significantly to the fall in the low-skilled employment share. Second, according to our results, the widely used current price measures of offshoring underestimate the extent of offshoring and its impact on low-skilled employment. Finally, we find that the impact of offshoring on low-skilled employment is significantly smaller in industries with a higher ICT capital intensity. This result also implies that even if ICT capital facilitates offshoring, especially of business services, this does not lead to faster skill upgrading in industries with a high ICT capital intensity.

Keywords: Materials and business services offshoring, labour demand, skill upgrading, educational attainment, ICT capital intensity

\section{CEB Working Paper No $12 / 020$ 2012}




\title{
Offshoring and the Skill Structure of Labour Demand in Belgium
}

\author{
Bart Hertveldt ${ }^{\mathrm{a}}$ \\ (Belgian Federal Planning Bureau) \\ $\&$ \\ Bernhard Michel ${ }^{\mathrm{a}, \mathrm{b}}$ \\ (Belgian Federal Planning Bureau, Université Libre de Bruxelles)
}

Keywords: Materials and business services offshoring, labour demand, skill upgrading, educational attainment, ICT capital intensity

\footnotetext{
${ }^{a}$ Federal Planning Bureau, Avenue des Arts 47-49, B-1000 Brussels, Belgium.

${ }^{\mathrm{b}}$ Corresponding author, e-mail: bm@plan.be, phone: + 3225077435.
} 


\title{
Offshoring and the Skill Structure of Labour Demand in Belgium
}

\begin{abstract}
A major concern regarding the consequences of offshoring is the worsening of the labour market position of low-skilled workers. This paper addresses this issue by providing evidence on the impact of offshoring on the skill structure of manufacturing employment in Belgium between 1995 and 2007. Offshoring is found to significantly lower the employment share of low-skilled workers. Its contribution to the fall in the employment share of low-skilled workers amounts to $35 \%$. This is mainly driven by offshoring to Central and Eastern European countries. Moreover, our analysis contains three extensions with respect to the existing literature. First, while previous papers exclusively focus on materials offshoring, we show that offshoring of business services also contributes significantly to the fall in the low-skilled employment share. Second, according to our results, the widely used current price measures of offshoring underestimate the extent of offshoring and its impact on low-skilled employment. Finally, we find that the impact of offshoring on low-skilled employment is significantly smaller in industries with a higher ICT capital intensity. This result also implies that even if ICT capital facilitates offshoring, especially of business services, this does not lead to faster skill upgrading in industries with a high ICT capital intensity.
\end{abstract}




\section{Introduction}

Over the past couple of decades, production processes have become increasingly fragmented: they are divided into ever smaller parts considered as separate activities, which are then spread over various locations in different countries. Hence, inputs into the production process are sourced not only from local but also from foreign suppliers. The latter mode of sourcing is commonly referred to as offshoring. It encompasses both manufacturing and service activities. A typical example for the former is the sourcing of materials from abroad, e.g. parts and components for car assembly. While the offshoring of manufacturing activities has been occurring since very long, the offshoring of service activities such as the provision of accounting or call centre services is a more recent phenomenon that has been fostered by the increased tradability of such services.

One of the main concerns in developed countries regarding the consequences of offshoring is about the worsening of the labour market position of low-skilled workers. Indeed, according to the traditional idea underlying offshoring, firms relocate low-skilled intensive stages of production to low-skilled abundant countries, thereby influencing the within-industry skill composition of labour demand. In other words, just like technological change, offshoring is generally believed to be skill-biased, shifting labour demand from low-skilled to high-skilled workers.

The issue of the changes in the skill structure of labour demand induced by offshoring has traditionally been addressed at the industry-level within the framework of a flexible cost function from which a system of cost or employment share equations by skill level is derived. Early papers for the US (in particular Feenstra and Hanson, 1996 and 1999) as well as subsequent ones for European countries (e.g. Strauss-Kahn, 2003, for France; Hijzen et al., 2005, for the UK; Ekholm and Hakkala, 2006, for Sweden) have 
found that offshoring of materials harms the relative position of low-skilled workers. Moreover, it is offshoring to low-wage countries in particular that leads to a worsening of the labour market position of low-skilled workers (Anderton and Brenton, 1999; Egger and Egger, 2003; Hsieh and Woo, 2005; Dumont, 2006; Geishecker, 2006).

This paper addresses the issue of the impact of offshoring on low-skilled employment for Belgium. Measuring skills by educational attainment, industry-level data show that there has been considerable skill upgrading of employment in Belgian manufacturing over the past 15 years. For this period, there is also evidence of increased offshoring where this is measured as the share of imported intermediates sourced from abroad. Offshoring of both materials and business services is on the rise in Belgian manufacturing industries. In order to determine to what extent offshoring has influenced the skill structure of labour demand in Belgium, we estimate an employment share equation for the low-skilled that is derived from a translog cost function and includes offshoring as well as variables accounting for technological progress. While the existing literature has focused exclusively on materials offshoring, we also take offshoring of business services into account and estimate its impact on low-skilled employment. In line with previous papers, we distinguish between materials offshoring to high-wage and lowwage countries. Furthermore, we investigate whether the impact of offshoring on the employment share of low-skilled workers differs between industries according to the technological content of their activity. Last but not least, almost all contributions in this field use a value measure of offshoring. As our dataset allows us to compute both constant price and current price measures of offshoring, we test for differences in their impact on the low-skilled employment share. 
The core of this paper is divided into five sections. The relevant empirical literature is reviewed in Section 2, while Section 3 contains stylised facts regarding skill upgrading and offshoring in Belgium. In Section 4, the model and the estimation strategy are presented. Econometric results are discussed in Section 5. Finally, concluding remarks are made in Section 6.

\section{Relevant Empirical Literature}

Within the vast body of academic literature on the consequences of globalisation for developed economies, a growing number of contributions have been looking specifically at offshoring measured by the share of imported intermediates in total intermediates. Among the possible consequences, the impact of offshoring on the skill structure of labour demand has been a major issue. It has become standard to investigate this issue within the framework of a flexible cost function - mostly translog - from which expressions for the input cost shares or factor demand shares are derived. Estimations of these expressions are almost exclusively based on industry-level data.

Feenstra and Hanson (1996) are the first to measure offshoring by the share of imported intermediates in total intermediates and to consider explicitly its impact on lowskilled and high-skilled labour proxied by production and non-production workers. Although they do not refer to a cost function, their approach is comparable as they regress the average annual growth in the wage share of non-production workers on that of materials offshoring plus controls for 435 US manufacturing industries. They find that offshoring has a significant positive impact for the period 1979-1990. A subsequent paper by the same authors - Feenstra and Hanson (1999) - distinguishes between narrow and 
broad offshoring $^{1}$ and extends the framework to include several alternative specifications of high-tech and computer capital. This lowers the contribution of materials offshoring to the rise in the non-production workers' wage share considerably.

In the wake of these two studies for the US, several papers have analysed this issue for - mostly large - European economies. Most of these papers explicitly define a cost function framework. Anderton and Brenton (1999) look at the effect of offshoring to low-wage countries on the wage bill and employment share of manual workers in six textile and five non-electrical machinery industries in the UK for the years 1970-1986. Their estimations in first differences indicate that this effect is negative. ${ }^{2}$ Falk and Koebel (2002) specify a Box-Cox cost function from which they derive a system of seven variable input demands including imported materials and three skill levels for labour measured by educational attainment. Estimating the parameters of this system with nonlinear SUR (seemingly unrelated regression) for 26 German manufacturing industries over 1978-1990, they find that the cross-price elasticities of the three skill levels with respect to imported materials are non-significant. However, in one of their specifications the elasticity of the demand for unskilled labour with respect to the volume of imported materials is significant negative. For France, Strauss-Kahn (2003) examines the impact of materials offshoring on the employment share of low-skilled workers in 50 manufacturing industries between 1977 and 1993. The distinction between high-skilled and low-skilled is defined in terms of occupations. Her estimation strategy is based on annual average changes just like in Feenstra and Hanson (1996). The results point to a

1 For broad offshoring, all imports of intermediates are taken into account for each industry, while for narrow offshoring, only intermediates from the same industry are considered.

2 It is, however, not entirely clear in this paper whether the authors replicate the standard offshoring measure of Feenstra and Hanson (1996) or just use total imports for the products corresponding to the industries in the sample. 
significant negative impact of narrow offshoring to both OECD and non-OECD countries on the low-skilled employment share.

The fall of the iron curtain led to an increased focus on offshoring to Central and Eastern European countries (CEEC). Egger and Egger (2003) look at Austrian manufacturing. Their sample covers 20 industries over 1990-1998 and skill levels are based on occupations. They regress the relative employment of high-skilled workers on narrow materials offshoring to CEEC using two-stage and three-stage least squares. According to the results, offshoring to CEEC has a significant positive impact, explaining about a quarter of the rise in this share. Geishecker (2006) investigates the same question for Germany, i.e. the threat of offshoring to CEEC for the low-skilled in manufacturing in the 90's. He estimates a cost share equation for production workers by generalised method of moments with data for 22 industries over 1991-2000 and finds a significant and sizeable negative effect of both narrow and broad materials offshoring to CEEC. A radical liberalisation similar to the one experienced by CEEC in the wake of the fall of the iron curtain is analysed in Hsieh and Woo (2005). Their paper is the exception to the rule of papers on European countries and looks at offshoring from Hong Kong to China triggered by China's opening up to foreign investment in 1980. Based on first difference and instrumental variable regressions, they find that this offshoring has had a significant downward effect on the production workers' wage bill share in Hong Kong's manufacturing industry over the years 1981 to 1996.

Furthermore, Hijzen et al. (2005) present evidence for the UK with skill levels based on occupations. They include narrow offshoring as an explanatory variable in systems of either cost shares or employment shares and apply fixed effects ISUR (iterated 
SUR) to estimate these with data for 50 manufacturing industries over 1982-1998. The results point to a strong negative impact of materials offshoring on the demand for 'unskilled' labour. The approach chosen in Ekholm and Hakkala (2006) is similar. These authors also estimate systems of either cost shares or employment shares, but use pooled ISUR, for 20 Swedish manufacturing industries between 1995 and 2002. In terms of results, they report a significant positive impact of offshoring to low-wage countries on labour demand for workers with tertiary education and the opposite for workers with upper secondary education.

Dumont (2006) tests two flexible cost functions (generalised Leontief and minflex Laurent generalised Leontief) to show that the choice of functional form may alter the impact of offshoring on the cost shares by skill level. He estimates a system of cost share equations by three-stage least squares separately for 12 manufacturing industries with data for the years 1985-1996 pooled over 5 EU countries (Belgium, Denmark, France, Germany and the UK). Low-skilled labour is proxied by manual workers. The results show that materials offshoring to high-skill abundant and low-skill abundant countries has, respectively, a positive and a negative impact on the cost share of low-skilled labour. Finally, Kratena (2010) treats offshoring as a direct substitution process between imported intermediate inputs on the one hand and labour of different skill levels and domestic inputs on the other hand. He estimates a set of cost share equations separately for three small open economies (Austria, Denmark and the Netherlands) by fixed effects ISUR for 13 manufacturing industries over the period 1995-2004 and finds positive cross-price elasticities for (almost) all skill levels. 
Firm-level evidence on the impact of offshoring on the skill structure of labour demand is scarce. Head and Ries (2002) investigate the issue for what they call "offshore production" with a firm-level dataset for Japan. They define offshore production as the share of employment in foreign affiliates and find that it raises a firm's share of non production workers. Nonetheless, this offshoring measure is different from the one based on imported intermediates. Using data for French manufacturing firms, Biscourp and Kramarz (2007) distinguish between imports of finished goods defined as goods that belong to same classification code as the importing firm, and imports of intermediate inputs that include all other goods imported by the firm. In line with the idea of narrow offshoring, they consider the share of imports of finished goods in total sales as an indicator of offshoring, and find that it has a significant negative effect on the share of production workers. Mion et al. (2010) replicate this measure with Belgian firm-level data. But it turns out that its impact on the skill intensity measured in terms of both occupations and educational attainment is either small or non-significant.

To sum up the results, the large consensus regarding the negative impact of offshoring on the demand for low-skilled labour stands out, especially for offshoring to low-wage countries. However, the offshoring of business services has been largely neglected in this literature. 


\section{Stylised facts}

The stylised facts presented in this section illustrate trends in employment by skill level and in offshoring intensities for Belgium. The industry-level data presented here cover 63 manufacturing industries, which are listed in Appendix Table A2. ${ }^{3}$

\subsection{Skill upgrading}

In Belgium, like in other European countries, there has been considerable skill upgrading of employment in terms of educational attainment in manufacturing over the past 15 years. This is shown in Graph 1 for the years 1995-2009. Distinguishing three levels of educational attainment, it can be seen that the share of workers with 'tertiary long' and 'tertiary short and higher secondary' education has increased at the expense of workers with 'primary and lower secondary' education. We will henceforth refer to the latter as low-skilled workers. The analysis that follows will be mainly focused on their labour market position. The other levels of educational attainment are grouped together in one category referred to as high-skilled workers. ${ }^{4}$ Between 1995 and 2009, the share of lowskilled workers has fallen from $53 \%$ to $31 \%$.

\section{[Insert Graph 1 here]}

Table 1 highlights that not only the share but also the absolute number of lowskilled workers has decreased dramatically. Between 1995 and 2009, employment of low-skilled workers in Belgian manufacturing dropped by more than $45 \%$ from 487000 to 261000 . This fall was partially offset by an increase in high-skilled workers. Overall, manufacturing employment decreased by $10 \%$, from 926000 to 830000 . When comparing the two sub-periods 1995-2002 and 2002-2009 in Table 1, we can see that the

3 Data sources are indicated in Appendix Table A2.

4 Despite the large differences in educational attainment within this second category, we have chosen to use the term high-skilled workers. 
skill upgrading of manufacturing employment slowed down somewhat, but remained substantial over the years 2002-2009.

[Insert Table 1 here]

Limiting the time span to $1995-2007^{5}$, two further stylised facts about skill upgrading deserve to be illustrated here. First, we examine to what extent the decline in the employment share of low-skilled workers comes from changes in employment between industries or within industries. Following Berman et al. (1994), the change in the aggregate share of low-skilled workers $\left(\Delta E^{t} L\right)$ can be decomposed into two components:

$$
\Delta E^{L}=\sum_{i=1}^{n} \overline{E_{i}^{L}} \Delta E_{i}+\sum_{i=1}^{n} \overline{E_{i}} \Delta E_{i}^{L}
$$

for $\mathrm{i}=1, \ldots, \mathrm{n}$ industries; $E_{i}^{L}$ is the share of low-skilled workers in employment of industry i, $E_{i}$ is the share of employment of industry i in total employment, and a bar over a term denotes a mean over time. The first term on the right-hand side is the between industries component; the second term is the within industries component.

Table 2 presents the results of the decomposition above for the period 1995-2007, revealing that the fall in the overall employment share of low-skilled workers overwhelmingly occurred within industries. In other words, between 1995 and 2007, shifts of employment away from industries with high shares of low-skilled workers (the between component) made almost no contribution to the observed overall skill upgrading.

[Insert Table 2 here]

5 This matches the period covered by the econometric analysis in section 4 . 
Second, it proves interesting to compare changes in the employment share of the low-skilled with changes in their wage bill share. Between 1995 and 2007, the wage bill share of low-skilled workers in manufacturing fell by roughly $40 \%$. Decomposing this change shows that about $90 \%$ was due to a decrease in relative employment of lowskilled workers and only $10 \%$ can be attributed to a fall in relative wages. This reflects that Belgium, like other continental European countries, has a less flexible labour market than for instance the US or the UK.

\subsection{Offshoring}

The scarcity of direct evidence regarding the transfer abroad of economic activities has prompted most authors in the field of offshoring to make use of the indirect measure suggested in Feenstra and Hanson (1996). ${ }^{6}$ It consists in measuring the industry-level intensity of offshoring by the share of imported intermediates in total non-energy inputs. ${ }^{7}$ A distinction can be made according to the type of intermediates that are sourced from abroad. It can be parts and components entering manufacturing processes, e.g. integrated electronic circuits used in computer assembly or lenses used in the production of optical instruments. When such materials are sourced from abroad, we call this materials offshoring. But offshoring may also concern business services, which encompass amongst others bookkeeping services, payroll services or legal advice. During the last couple of decades, such business services have become increasingly tradable due to developments in information and communications technology and service trade

6 The shortcomings of this indirect measure are summarised in Michel and Rycx (2012, p.230): “..., it ignores cases of offshoring that do not give rise to imports and includes imports that are not due to offshoring. Moreover, focusing on intermediates implies leaving out cases where the final stage of the production process is offshored." Nonetheless, in the absence of direct evidence on the transfer abroad of economic activities, it can reasonably be taken to be the best indirect measure of offshoring.

7 Some authors divide by output, e.g. Ekholm and Hakkala (2006) or Geishecker (2006), and some even by value added, e.g. Hijzen et al. (2005). 
liberalisation. This has made it easier to source them from abroad. When such services are provided by foreign suppliers, we call this business services offshoring. Hence, following Amiti and Wei (2005), we define materials offshoring (OM) and business services offshoring $(O S)$ as:

$O M_{i}=\frac{\boldsymbol{\Sigma}_{m} I M M_{m i}}{I_{i}} \quad O S_{i}=\frac{\boldsymbol{\Sigma}_{s} I I S_{s i}}{I_{i}}$

where IIM stands for imported intermediate materials, IIS for imported intermediate business services and $I$ for total non-energy inputs, $i$ is the industry index, $m$ the index for materials and $s$ the index for business services.

These offshoring intensities can be computed from input-output tables (IOT) or supply-and-use tables (SUT) and more specifically from the use table of imports, which contains information on imported intermediates by industry. ${ }^{8}$ Furthermore, the imported intermediates can be split according to the country of origin of the imports so as to distinguish between offshoring to different countries, in particular between high-wage and low-wage countries. Such splits are computed by a proportional method since use tables of imports by country of origin do not exist. The proportional computation of the amount of imported intermediates from country $c$ for industry $i$ implies multiplying the amount of imported intermediates for each product by the share of country $c$ in total imports of that product. Hence, write:

$$
o M_{\Sigma_{i}}=\frac{\sum_{m} \frac{M_{m v}}{M_{m}} I M M_{m i}}{I_{i}} \quad 0 S_{v_{i}}=\frac{\sum_{s} \frac{M_{s c}}{M_{s}} I I S_{s i}}{I_{i}}
$$

8 In line with the initial approach in Feenstra and Hanson (1996), some authors, e.g. Egger and Egger (2003) or Ekholm and Hakkala (2006), compute the offshoring intensity for industry $i$ by multiplying the amount of intermediates of each product by the share of imports in total supply for that product. This so-called 'proportional method' is applied when use tables of imports are not available. 
where $O M_{-} c$ and $O S \_c$ stand for materials and business services offshoring intensities to country $c, M_{m}$ or $M_{s}$ is total imports of material $m$ or business service $s$ and $M_{m c}$ or $M_{s c}$ is imports of material $m$ or business service $s$ from country $c$.

For Belgium, total materials and business services offshoring can be computed with data from a series of constant price SUT for the years 1995 to 2007 that is described in Avonds et al. (2012). ${ }^{9}$ Use tables of imports are contained in this database. Their construction is based on the original method described in Van den Cruyce (2004) for the input-output reference years 1995, 2000 and 2005. This method makes use of crosstabulated import data by firm and product so as to allow for identification of intermediates that have been imported. For non reference years, the shares of imported intermediates by industry and product have been first interpolated and then multiplied with total intermediates by industry and product in order to obtain a table of imported intermediates. A balancing procedure is then used to adapt this table so as to respect import totals by product. Materials and business services are defined here in terms of product categories of the $\mathrm{CPA}^{10}$ by products $15-37$ (except for energy products) and 7274 respectively. Using detailed import data by country of origin and product $^{11}$, we calculate offshoring intensities for three regions: OECD, which includes 22 OECD member states ${ }^{12}$, CEEC, which corresponds to ten Central and Eastern European

\footnotetext{
These tables are deflated using a separate price index for imports and domestic production for each product.

10 Standard Classification of Products by Activity in the European Community (CPA2002 version).

11 The data on the geographic distribution of imports come from Intrastat and Extrastat for goods (the 8-digit Combined Nomenclature data are aggregated to the level of the product classification in our SUT) and from the balance of payments for services (categories 'Computer and information services' (7) and 'Miscellaneous business, professional and technical services' (9.3)).

12 Austria, Australia, Canada, Denmark, Finland, France, Germany, Greece, Iceland, Ireland, Italy, Japan, Luxemburg, the Netherlands, New Zealand, Norway, Portugal, Spain, Sweden, Switzerland, the UK and the US. These countries plus Turkey were the OECD member states by the middle of the 1970's.
} 
countries $^{13}$, and ASIA, which includes eight newly industrialised economies of Asia as well as China and India ${ }^{14}$.

Trends in offshoring are shown in Table 3. Starting from a high level of $35.7 \%$ in 1995 , the intensity of materials offshoring in manufacturing grows relatively slowly to reach $38.3 \%$ in 2007 . Business services offshoring is at a much lower level, but grows relatively fast from $0.7 \%$ in 1995 to $1.9 \%$ in 2007 . The figures for the regional offshoring intensities show that offshoring to OECD countries largely dominates for both materials and business services. Especially for the latter, offshoring to CEE and Asian countries is still very small during the period considered here. Nonetheless, it stands out from Table 3 that between 1995 and 2007 offshoring to Asian and CEE countries grows fastest for both materials and business services.

\section{[Insert Table 3 here]}

The possibility of computing volume measures of offshoring is particularly important since value measures tend to underestimate the extent of offshoring. Indeed, activities are generally being offshored in order to make cost savings, i.e. because imported intermediates are cheaper than domestically produced intermediates. Then, the growth in the offshoring intensity in value terms can be expected to be biased downwards. This is exactly what we find when computing offshoring intensities in current and constant prices from the corresponding SUT as illustrated by their average growth rates shown in Table 4.

\section{[Insert Table 4 here]}

13 Bulgaria, the Czech Republic, Estonia, Hungary, Latvia, Lithuania, Poland, Romania, the Slovak Republic and Slovenia.

14 China, Hong Kong, India, Indonesia, Malaysia, the Philippines, Singapore, South Korea, Thailand and Taiwan. 


\section{Model specification}

In line with most empirical literature in this field, we specify a model based on the translog cost function to analyse the impact of offshoring on the skill structure of labour demand. Belonging to the category of flexible functional forms, one attractive feature of the translog cost function is that it puts no a priori restrictions on elasticities. Instead of estimating the translog cost function directly, it is more convenient to estimate a system of cost share equations derived from it.

The translog cost function is presented in its most general form in the Appendix. The model estimated below departs in a number of ways from the general outline given in equation (A.4) in the Appendix. First, on the left-hand side, we replace cost shares by employment shares. As argued above, Belgium has, like other continental European countries, a rather rigid labour market compared with the UK or the US. Hence, the deterioration of the relative position of low-skilled workers is primarily reflected in the structure of employment and less by the wage gap between low-skilled and high-skilled workers. ${ }^{15}$ Moreover, replacing wage bill shares by employment shares reduces the potential endogeneity problem stemming from the presence of wages on the right-hand side of the system of equations. Endogeneity leads to inconsistent estimators. In the case of a cost share model, endogeneity is highly likely given the relationship between the

15 Employment share specifications are also the preferred model choice for France in Strauss-Kahn (2003) and for Austria in Egger and Egger (2003).They have also been tested as an alternative specification or robustness check by other authors, e.g. Anderton and Brenton (1999), Hijzen et al. (2005) and Ekholm and Hakkala (2006). 
dependent variable, i.e. the cost share of labour, and the (relative) wage term. ${ }^{16}$ But even in an employment share model, there is a potential problem of simultaneity between the employment share and the relative wage. Finally, while cost shares are expressed in monetary terms, employment shares are expressed in numbers of persons or hours worked. ${ }^{17}$ Hence, employment share specifications necessarily exclude input factors other than labour.

As in most other studies, capital is taken to be a quasi-fixed factor. By treating capital as exogenous in the short-term, we assume that adjustment costs exist and prevent capital to attain its long-term equilibrium level. In line with theory, we include the capital stock rather than capital-intensity. ${ }^{18}$ Furthermore, the capital stock is split into ICT and non-ICT capital (see Table A2 on data sources in the Appendix).

We extend the standard translog cost framework by including two types of demand shifters. The first is offshoring, both materials and business services offshoring. Furthermore, we include the R\&D intensity, which - together with the ICT capital stock - controls for skill-biased technological change. ${ }^{19}$ Accordingly, our model takes the following form:

$$
\begin{aligned}
& \left.E_{i t}^{L}=\beta_{L}+\delta_{L L} \ln W_{i t}^{L}+\delta_{L H} \ln W_{i t}^{H}+\delta_{L Y} \ln Y_{i t}+\delta_{L K} \ln K_{i t}+\gamma_{L R} R D_{i t}+\gamma_{L M} O M_{i t}+\gamma_{L S} O S_{i t}\right) \\
& \left.\left.E_{i t}^{H}=\beta_{H}+\delta_{H L} \ln W_{i t}^{L}+\delta_{H H} \ln W_{i t}^{H}+\delta_{H Y} \ln Y_{i t}+\delta_{H K} \ln K_{i t}+\gamma_{H R} R D_{i t}+\gamma_{H M} O M_{i t}+\gamma_{H S} O\right)_{9}\right)
\end{aligned}
$$

16 However, in a test with data for Germany, Geishecker (2006) fails to reject the exogeneity of the relative wage in a regression for the cost share of low-skilled workers.

17 Hours worked by skill level are not available for Belgium. Hence, just like all other paper in this literature, we use data on the number of persons.

18 In several papers, the capital intensity is used as a regressor instead of capital stock, e.g. Feenstra and Hanson (1996, 1999), Hsieh and Woo (2005) and Geishecker (2006).

19 We explicitly refrain from including variables that may indirectly also account for technological progress such as a time trend. Baltagi and Rich (2005) is an example of the use of the latter for modelling technological progress. 
where $E_{i}^{L}$ and $E_{i}^{H}$ denote industry $i$ 's employment share of the low-skilled $(L)$ and high-skilled $(H)$ workers, $W_{i}^{L}$ and $W_{i}^{H}$ denote the corresponding industry specific wage rates ${ }^{20}, Y$ is value added, $K$ is capital stock, $R D$ is $\mathrm{R} \& \mathrm{D}$ intensity, $O M$ is materials offshoring and $O S$ is business services offshoring.

As explained in the Appendix, we can now apply, without loss of generality, the symmetry condition $\hat{\delta}_{L H}=\hat{\partial}_{H L}$. Moreover, a 'well-behaved' cost function should be homogeneous of degree 1 in prices, which imposes the set of restrictions (A.2) given in Appendix 1. Applying all these restrictions to the model above, it follows that:

$$
\begin{gathered}
\beta_{L}+\beta_{H}=1 \\
\delta_{L L}=\delta_{H H}=-\delta_{L H}=-\delta_{H L} \quad \delta_{L Y}=-\delta_{H Y} \quad \delta_{L K}=-\delta_{H K} \\
\gamma_{L R}=-\gamma_{H R} \quad \gamma_{L M}=-\gamma_{H M} \quad \gamma_{L S}=-\gamma_{H S}
\end{gathered}
$$

Given restrictions (3), our model is reduced to one single equation. Adding industry dummies $D_{i}$ and a stochastic error term $u_{i t}$, the specification to be estimated is:

$$
\left.E_{i t}^{L}=\beta_{L}+\delta_{L L} \ln \left(\frac{W_{i t}^{L}}{W_{i t}^{H}}\right)+\delta_{L Y} \ln Y_{i t}+\delta_{L K} \ln K_{i t}+\gamma_{L R} R D_{i t}+\gamma_{L M} O M_{i t}+\gamma_{L S} O S_{i t}+\theta_{i} D_{i}+2\right)
$$

In (4), the impact of materials and business services offshoring on the employment share of low-skilled workers is given by the coefficients $\gamma_{L M}$ and $\gamma_{L S}$. The own-price elasticities of low-skilled and high-skilled workers can be calculated using the estimated coefficient $\hat{\delta}_{L L}$ and the fitted value $\hat{E}^{L}$ :

$$
\varepsilon_{L L}=\frac{\hat{\delta}_{L L}}{\hat{E}^{L}}-\left(1-\hat{E}^{L}\right) \quad \varepsilon_{H H}=\frac{\hat{\delta}_{L L}}{\left(1-\hat{E}^{L}\right)}-\hat{E}^{L}
$$

\footnotetext{
20 The wage rate is expressed as the wage cost per employee.
} 
Modelling a set of industry equations implicitly limits the analysis to within industry skill upgrading. In our case, however, this is not really a limiting factor, as during the period considered here almost all skill upgrading occurred within and not across industries.

\section{Results}

In this section, estimation results for equation (4) are discussed. Data sources and descriptive statistics for the variables that have not been discussed in the previous section are reported in the Appendix (Tables A2 and A3). ${ }^{21}$ A number of studies, e.g. Feenstra and Hanson (1996), Anderton and Brenton (1999), Strauss-Kahn (2003) and Egger and Egger (2003), estimate the model by taking first differences in order to control for industry specific time-invariant effects. However, according to Griliches and Hausman (1986) using first differences tends to exacerbate potential problems of measurement error in the data. Hence, we prefer to estimate equation (4) in levels by fixed effects, as is also done in Hijzen et al. (2005) and Kratena (2010). Given that we focus on a single employment share equation our model is closest to that of Geishecker (2006).

\subsection{Impact of total offshoring}

We start by estimating equation (4) with total offshoring intensities by fixed effects (fe). The results are shown in column (a) of Table $6 . \mathrm{R} \& \mathrm{D}$ intensities are only available at a higher level of aggregation than the other variables. ${ }^{22}$ Therefore, standard errors are corrected for clustering so as to avoid the bias discussed in Moulton (1990).

21 We have also added descriptive statistics for the dependent variable, i.e. the low-skilled employment share, so as to show the variation for the period covered by the estimations (1995-2007).

22 The R\&D-intensity is defined as the industry-level R\&D stock divided by output. Its level of aggregation is 2-digit Nace Rev.1.1 (16 industries for manufacturing) instead of the more detailed SUT classification in the Appendix. 
However, as mentioned earlier, there is a potential endogeneity issue regarding the relative wage as explanatory variable in equation (4) since industry-level wages and employment by skill-level may be determined simultaneously. The same argument may hold for the offshoring intensities, which may be chosen together with the low-skilled employment share thereby leading to an endogeneity problem. Failure to take this into account entails inconsistent coefficient estimates for all variables. This is traditionally addressed through instrumental variable regression even though the estimation becomes less efficient. ${ }^{23}$ We instrument the relative wage and the offshoring intensities using their one-year and two-year lags. As a first step, we conduct separate endogeneity tests for these variables. ${ }^{24}$ The results are reported in Table 5. The null hypothesis of exogeneity is only rejected for the relative wage. Hence, we estimate equation (4) by two-stage least squares (2sls) with fixed effects instrumenting the relative wage by its one-year and twoyear lags while taking the offshoring intensities as exogenous. The main change compared with the fixed effects regression occurs for the instrumented variable (see columns (a) and (b) of Table 6). Furthermore, we have also estimated this model with endogenous relative wage by generalised method of moments (gmm). ${ }^{25}$ The differences in the results (reported in column (a) of Appendix Table A4) compared with the 2sls estimation are small in terms of both magnitude and significance of the coefficients.

23 The stata module xtivreg2 (Schaffer, 2010) is used for all instrumental variables and GMM regressions in this paper. For more details on this module, see Baum et al. (2003 and 2007).

24 It is in fact an exogeneity test, i.e. "under the null hypothesis the specified endogenous regressor can actually be treated as exogenous" (Baum et al., 2007, p.482). The test reported in Table 4 is equivalent to a C or GMM distance test where the test statistic is distributed as a $\chi^{2}$ with a number of degrees of freedom equal to the number of potentially endogenous regressors, and, with homoskedastic errors, it is identical to the Wu-Hausman F-test for endogeneity (Baum et al., 2003, pp.23-25). In our case, it is necessary to account for clustered standard errors due to the higher level of aggregation of the R\&D intensity variable.

25 As explained in Baum et al. (2003, p.11), estimation by gmm is generally more efficient than 2sls estimation due to the use of the optimal weighting matrix. However, the estimation of this matrix requires a large sample size and the properties of the gmm estimator may therefore be poor in small samples, notably leading to over-rejection of the null hypothesis in Wald tests. 
[Insert Table 5 here]

According to the results of the 2sls regression in column (b) of Table 6, both materials and business services offshoring have a statistically significant negative impact on the employment share of low-skilled workers, i.e. they contribute to reducing the relative demand for low-skilled labour in a setting where relative wage trends and skillbiased technological change are controlled for. Regarding the relative wage in this specification, its negative and significant coefficient is broadly in line with what may be expected based on theory and empirical results for other countries. Own-price elasticities for low-skilled and high-skilled workers, calculated according to (5), based on estimates in Table 6 are reported in Appendix Table A5. ${ }^{26}$ Both are negative and strongly significant (column (b) of Table A5). Furthermore, neither of the two variables measuring skill-biased technological change (the R\&D intensity ${ }^{27}$ and the ICT capital stock) has a significant impact on the low-skilled employment share ${ }^{28}$, whereas the non-ICT capital stock has a strongly significant negative impact. Our interpretation of this finding is that it is investment in specialised machinery and equipment for manufacturing rather than investment in computers and other ICT-equipment that puts pressure on low-skilled employment in manufacturing. Finally, we find no effect of value added on the lowskilled employment share.

[Insert Table 6 here]

26 The values and standard errors of the elasticities reported in Table A5 are based on the fitted employment shares for the last year of the dataset (i.e. 2007). The columns of Table A5 correspond to those of Table 6.

27 The p-value of the R\&D intensity amounts to 0.11 for the estimation in column (b). Without the cluster correction, it would be significant at the $5 \%$-level. However, it should be noted that in our case the R\&D intensity would contribute to raising the low-skilled employment share given the overall fall in the R\&D intensity in manufacturing between 1995 and 2007 (see Appendix Table A3). The contribution of the R\&D intensity would, however, be small (less than $0.5 \%)$.

28 The two variables are not jointly significant either: the p-value of a joint Wald test for the R\&D intensity and the ICT capital stock is 0.1719 . 
Contributions to the change in the low-skilled employment share can be calculated for the offshoring intensities and the non-ICT capital stock based on their coefficients in column (b). Materials offshoring and business services offshoring rise by respectively 2.65 and 1.23 percentage points between 1995 and 2007, accounting for respectively $2 \%$ and $10 \%$ of the fall in the low-skilled employment share during that period. The contribution of the increase in the non-ICT capital stock to the observed fall in the low-skilled employment share amounts to 24\% between 1995 and 2007.

We have produced three extensions to the specification with the total offshoring intensities, which all imply 2 sls regressions with fixed effects using one-year and twoyear lags as instruments for the relative wage. Results are reported in columns (c) - (e) of Table $6 .^{29}$

First, given the differences in the growth rates of the offshoring intensities in value and volume terms shown in Table 4, we estimate equation (4) replacing the offshoring intensities in constant prices by their current price counterparts. This is of particular interest as most of the papers reviewed in section 2 use non-deflated SUT or IOT to compute the offshoring intensities that enter into the estimated equations. ${ }^{30}$ The results are reported in column (c) of Table 6. Comparing them with results in column (b) shows that using current price offshoring intensities leads to an underestimation of the impact on the low-skilled employment share. The coefficients for both materials and business services offshoring are smaller in current prices than in constant prices and the one for materials offshoring even becomes non-significant in current prices. Moreover,

29 Own-price elasticities for high-skilled and low-skilled labour for these regressions can be found in columns (c) - (e) of Appendix Table A5. They are very close in terms of size to those for the standard specification in column (b). To complete the results, we have also run gmm estimations for the specifications in columns (c) - (e) of Table 6 (see columns (b) - (d) of Appendix Table A4). There are no substantial differences compared with the 2sls estimations.

30 Only, Falk and Koebel (2002), Geishecker (2006) and Kratena (2010) explicitly mention the deflation of their intermediate input data. 
the $\mathrm{R}^{2}$ of the estimation with current price offshoring intensities is lower. This confirms that deflated SUT should be preferred for computing the offshoring intensities.

Second, in order to enhance our understanding of the relationship between offshoring and the technological content of activities, we test for differences in the impact of offshoring on low-skilled employment between high-tech and low-tech industries. In high-tech industries, production processes are less standardised, have a higher knowledge content and require more sophisticated inputs, which makes offshoring more difficult and less profitable - especially for very specific materials inputs. As a consequence, the impact of offshoring on the low-skilled employment share may be expected to be weaker in high-tech industries. A classification of high-tech and low-tech industries is put forward in OECD (2005, pp.181-183). Based on this classification we create a high-tech dummy (Hitech). ${ }^{31}$ While the fall in the low-skilled employment share between 1995 and 2007 is almost identical in high-tech and low-tech industries (respectively 18 and 19 percentage points), materials offshoring stagnates in the former and grows moderately by 4 percentage points in the latter. Moreover, business services offshoring rises faster in high-tech industries ( 2 percentage points) than in low-tech industries (1 percentage point). Estimating equation (4) with interaction terms between the high-tech dummy and respectively materials and business services offshoring confirms the reasoning above (column (d) in Table 6). For both materials and business services offshoring, the coefficients of the offshoring variable and the respective interaction term with the hightech dummy are individually and jointly significant. ${ }^{32}$ Materials offshoring has a stronger

\footnotetext{
Industries 24A-24G and 29A-35B from the code list in Appendix Table A1 are considered high-tech.

32 Wald test for joint significance of

- $\quad \mathrm{OM}$ and $\mathrm{OM}^{*}$ Hitech: test-stat $\left[\chi^{2}(1)\right]=10.67, \mathrm{p}$-value $=0.004$

- $\quad$ OS and OS* Hitech: test-stat $\left[\chi^{2}(1)\right]=34.51, \mathrm{p}$-value $=0.005$
} 
impact in low-tech industries (-0.234), and its coefficient for high-tech industries (0.058) is not significant. In low-tech industries, the contribution to the fall in the employment share of low-skilled workers is close to $5 \%$ for the average increase in materials offshoring in these industries. Business services offshoring has a significant negative effect on the low-skilled employment share in both low-tech and high-tech industries. The effect is again weaker in the latter (-1.048 compared with -2.093$)$, but, due to the difference in the average increase in business services offshoring, the contribution to the fall in the low-skilled employment share amounts to approximately $10 \%$ for both. ${ }^{33}$

Third, instead of interacting the offshoring intensities with a rough and arbitrarily defined high- tech dummy, we interact materials and business services offshoring with the ICT capital intensity (ICT_VA) measured as the ICT capital stock normalised by value added. The expected effect of including these interaction terms into equation (4) is less clear than in the case of the high-tech dummy. On the one hand, the ICT capital intensity may be seen as an alternative indicator of the technological content of an activity and the same reasoning as for the distinction between high-tech and low-tech industries should hold, i.e. offshoring is more difficult to put into practice in industries with a higher ICT capital intensity and, as a consequence, the impact of offshoring on the low-skilled employment share is expected to be weaker in these industries. On the other hand, ICT capital is a potential driver for offshoring decisions, especially for business services that have become tradable through developments in information and communication technology. Indeed, ICT capital enables business services offshoring, and, in general, makes it easier to coordinate activities in different locations. Hence, if ICT capital promotes offshoring, then we would expect the negative impact of offshoring

33 We have also interacted the R\&D intensity with the high-tech dummy, but this did not produce significant results. 
on the low-skilled employment share to be stronger in industries with a higher ICT capital intensity. The results of the estimation of equation (4) with these interaction terms are reported in column (e) of Table 6. For both materials and business services offshoring, the coefficients of the offshoring variable and the respective interaction term with the capital intensity are jointly significant. ${ }^{34}$ The results show that for materials offshoring it is the former of the two described effects that dominates since the impact of the materials offshoring intensity on the employment share of low-skilled workers is greater for industries with a lower ICT capital intensity. For business services offshoring, there is no significant difference in the impact on the low-skilled employment share between industries with high and low ICT-capital intensities as the interaction term is not individually significant. For the average ICT capital intensity, the contributions to the fall in the low-skilled employment share - computed based on the average increase in materials and business services offshoring - are in line with the standard specification: $2.2 \%$ for materials offshoring, and $10.1 \%$ for business services offshoring. ${ }^{35}$

\subsection{Impact of regional offshoring}

The possibility of splitting the offshoring intensities by region has been discussed above. We include regional offshoring intensities for materials offshoring in equation (4). ${ }^{36} \mathrm{~A}$ first estimation is again done by fixed effects (fe). Results are presented in column (a) of Table 8 . We also test for endogeneity of the regional materials offshoring intensities -

34 Wald test for joint significance of

- $\quad$ OM and $\mathrm{OM}^{*} \mathrm{ICT}$ VA: test-stat $\left[\mathrm{X}^{2}(1)\right]=20.62, \mathrm{p}$-value $=0.000$

- $\quad$ OS and OS* ICT_VA: test-stat $\left[\chi^{2}(1)\right]=44.04$, p-value $=0.000$

35 As the impact of materials offshoring varies significantly according to the ICT capital intensity, we have also computed the interval of contributions (for the average absolute change in materials offshoring) between the last and the first decile of the ICT capital intensity distribution (p90 and p10 since the impact of OM decreases with ICT_VA). It extends over $[1.9 \% ; 2.6 \%]$.

36 We have included offshoring intensities for the three above-mentioned regions as well as the rest of the world (OTHER) in the equation. Moreover, we have decided not to split business services offshoring by region since it is almost entirely limited to the OECD region. 
separately for each of the regional variables using their one-year and two-year lags as instruments.

[Insert Table 7 here]

According to the results for the tests reported in Table 7, none of them is endogenous. Hence, we only instrument for the relative wage and estimate the model by 2sls with fixed effects (column (b) of Table 8). As before, the main difference compared with the fixed effects estimation concerns the relative wage. ${ }^{37}$ However, there is also a noteworthy fall in the coefficient of materials offshoring to CEE countries. Finally, the gmm-estimation results in column (c) are very similar to the 2sls-estimation results.

According to the results in column (b) of Table 8, materials offshoring to CEE and Asian countries as well as to the rest of the world (OTHER) has a significant negative impact on the low-skilled employment share, whereas materials offshoring to OECD countries does not influence this share. In other words, it is mainly offshoring to the typical offshoring destinations in Central and Eastern Europe and Asia that affects the relative demand for low-skilled workers. Moreover, comparing these results with the previous ones obtained with total materials offshoring, it stands out that composition matters for the magnitude of the impact of materials offshoring. Aggregating offshoring to $\mathrm{CEE}$ and Asian countries with offshoring to OECD countries contributes to masking the real size of their effect. Regarding the coefficients for the other variables, those for the relative wage, the non-ICT capital stock and services offshoring are negative significant as in the specification with total materials offshoring in Table 6 (column (b)).

\footnotetext{
37 The own-price elasticities for low-skilled and high-skilled labour are very close to those reported in Table A5 and all are significant at the $1 \%$-level: respectively -0.785 (standard error $=0.264$ ) and $-0.407(0.132)$ for the fe estimation, and respectively $-1.387(0.167)$ and $-0.697(0.0767)$ for the 2 sls estimation.
} 
The main change in these coefficients is that the impact of the latter two variables has become smaller (in absolute value).

\section{[Insert Table 8 here]}

As previously, contributions to the overall fall in the employment share of lowskilled workers can be calculated. For the three significant regional materials offshoring intensities - to CEEC, ASIA and OTHER - they amount to respectively $21 \%, 2 \%$ and $4 \%$. Hence, the total contribution of materials offshoring is $27 \%$. Given the $8 \%$ contribution of business services offshoring in this specification, the overall fall in the low-skilled employment share that is due to offshoring adds up to $35 \%$. The accumulation of non-ICT capital accounts for a contribution of $17 \%$. The difference with the contributions in the specification with total materials offshoring is striking: the one of offshoring is now three times as big and no longer driven by business services offshoring, but by materials offshoring - overall and to CEE countries in particular.

\section{Conclusion}

Among the consequences of offshoring, a major concern for policy makers in developed economies is that offshoring may contribute to worsening the labour market position of low-skilled workers, either by putting pressure on their wages or by reducing their relative employment. While Dumont et al. (2012) show for Belgium that offshoring has indeed weakened the bargaining power of low-skilled workers, this paper provides evidence on the impact of offshoring on the skill structure of employment in manufacturing industries in Belgium over the period 1995-2007. 
Skill upgrading has been substantial in Belgian manufacturing. Between 1995 and 2007, the share of workers with primary or lower secondary education has fallen from $53 \%$ to $34 \%$. Regarding offshoring, three major trends can be identified: first, materials offshoring had already reached a high level in 1995 and kept on growing slowly; second, business services offshoring was only at its beginnings in the wake of service trade liberalisation and communication technology developments, but has started to grow fast; third, offshoring to CEE and Asian countries has been increasing at the fastest pace.

Estimations of the impact of offshoring on skill upgrading in manufacturing in this paper are based on a low-skilled employment share equation that can be derived from a translog cost function. It is augmented to take into account offshoring - through the share of imported intermediates sourced from abroad - as well as skill-biased technological change - through the R\&D intensity and the capital stock variables. According to the results of the estimations, the contribution of offshoring to the fall in the employment share of low-skilled workers amounted to roughly 35\% between 1995 and 2007. It largely exceeded the joint contribution of the technological change variables $(17 \%)$. The impact of offshoring on the low-skilled employment share mainly came from materials offshoring to CEE countries (contribution of 21\%), while offshoring to OECD countries had no effect. However, it is by no means only materials offshoring that influences low-skilled employment. We have shown that business services offshoring also has a significant effect and accounted for $8 \%$ of the fall in the employment share of low-skilled workers. Moreover, as our results imply that offshoring has a significant and sizeable effect on the skill composition of employment, they are an important complement to the previous finding that neither materials nor business services 
offshoring has had a significant impact on overall industry-level employment in Belgium between 1995 and 2003 (Michel and Rycx, 2012).

We have provided further extensions compared with the existing literature. First, we have shown that a current price offshoring intensity measure underestimates the growth in offshoring, which is consistent with the idea that intermediates sourced from abroad are cheaper than domestically sourced intermediates. As a consequence, the impact of offshoring on low-skilled employment is also underestimated when using a current price measure as done in most of the literature. Furthermore, we have tested to what extent the technological content of an activity alters the impact of offshoring on low-skilled employment, either by splitting industries arbitrarily into high-tech and lowtech, or by ordering them according to their ICT capital intensity. It turns out that this impact is smaller in industries with a higher technological content or a higher ICT capital intensity. Finally, the latter finding also implies that even if ICT capital facilitates or even fosters offshoring, especially of business services, this does not lead to faster skill upgrading in industries with a high ICT capital intensity.

\section{References}

Amiti, Mary and S.-J. Wei (2005), 'Fear of Service Outsourcing: Is It Justified?', Economic Policy, 20, 42, 308-47.

Anderton, B. and P. Brenton (1999), 'Outsourcing and low-skilled workers in the UK', Bulletin of Economic Research, 51, 4, 267-285

Avonds, L., G. Bryon, C. Hambÿe, B. Hertveldt, B. Michel and B. Van den Cruyce (2012), 'Supply and Use Tables and Input-Output Tables for Belgium 1995-2007: 
Methodology of Compilation', Federal Planning Bureau, Working Paper 6-12, Brussels

Baltagi, B. and D. Rich (2005), 'Skill-biased technical change in US manufacturing: a general index approach', Journal of Econometrics, 126, 2, 549-570

Baum, C., M. Schaffer and S. Stillman (2003), 'Instrumental Variables and GMM: Estimation and Testing', The Stata Journal, 3, 1, 1-31

Baum, C., M. Schaffer and S. Stillman (2007), 'Enhanced routines for instrumental variables/ GMM estimation and testing', The Stata Journal, 7, 4, 465-506

Berman, E., J. Bound and Z. Griliches (1994), 'Changes in the Demand for Skilled Labor within U.S. Manufacturing: Evidence from the Annual Survey of Manufactures', The Quarterly Journal of Economics, 109, 2, 367-397

Berndt, E. (1991), The Practice of Econometrics: Classics and Contemporary, AddisonWesley, Reading, MA

Berndt, E. and D. Wood (1975), 'Technology, Prices, and the Derived Demand for Energy', The Review of Economics and Statistics, 57, 3, 259-268

Biatour, B., G. Bryon and C. Kegels (2007), 'Capital services and total factor productivity measurements: impact of various methodologies for Belgium', Federal Planning Bureau, Working Paper 3-07, Brussels

Biatour, B., M. Dumont and C. Kegels (2011), 'The determinants of industry-level total factor productivity in Belgium', Federal Planning Bureau, Working Paper 7-11, Brussels

Biscourp, P. and F. Kramarz (2007), 'Employment, skill structure and international trade: Firm-level evidence for France', Journal of International Economics, 72, 1, 22-51 
Bresseleers, V., K. Hendrickx, B. Hertveldt, B. Van den Cruyce and J. Wera (2007), 'Kwalitatieve werkgelegenheidsdata voor België, een SAM-aanpak voor de periode 1999-2005', Federal Planning Bureau, Working Paper 2-07, Brussels

Christensen, L., D. Jorgenson and L. Lau (1971), 'Conjugate Duality and the Transcendental Logarithmic Production Function', Econometrica, 39, 4, 255-256

Coucke, K. and L. Sleuwaegen (2008), 'Offshoring as a survival strategy: evidence from manufacturing firms in Belgium', Journal of International Business Studies, 39, 8, $1261-1277$

Crino, R. (2009), 'Offshoring, multinationals and the labour market: a review of the empirical literature', Journal of Economic Surveys, 23, 2, 197-249

Deardorff, A. (2006), 'Comment on Mankiw and Swagel, 'The politics and economics of offshore outsourcing', Journal of Monetary Economics, 53, 5, 1057-1061

Dumont, M. (2006), 'Foreign outsourcing, labour demand and the choice of functional form', Journal of Applied Economics, IX, 2, 255-273

Dumont, M. (2008), 'Wages and employment by level of education and occupation in Belgium', Federal Planning Bureau, Working Paper 22-08, Brussels

Dumont, M., G. Rayp and P. Willemé (2012), 'The bargaining position of low-skilled and high-skilled workers in a globalising world', Labour Economics, 19, 312-319

Egger, H. and P. Egger (2003), 'Outsourcing and skill-specific employment in a small economy: Austria after the fall of the Iron Curtain', Oxford Economic Papers, 55, 4, $625-643$ 
Egger, P., M. Pfaffermayr and Y. Wolfmayr-Schnitzer (2001), 'The international fragmentation of Austrian manufacturing: The effects of outsourcing on productivity and wages', North American Journal of Economics and Finance, 12, 3, 257-272

Ekholm, K. and K. Hakkala (2006), 'The Effect of Offshoring on Labor Demand: Evidence from Sweden', Research Institute of Industrial Economics, Working Paper $\mathrm{n}^{\circ} 654$, Stockholm

Falk, M. and B. Koebel (2002), 'Outsourcing, Imports and Labour Demand', Scandinavian Journal of Economics, 104, 4, 567-586

Feenstra, R. and G. Hanson (1996), 'Globalisation, Outsourcing, and Wage Inequality', American Economic Review, 86, 2, 240-245

Feenstra, R. and G. Hanson (1999), 'The Impact of Outsourcing and High-Technology Capital on Wages: Estimates for the United States, 1979-1990', The Quarterly Journal of Economics, 114, 3, 907-940

Geishecker, I. (2006), 'Does Outsourcing to Central and Eastern Europe Really Threaten Manual Workers' jobs in Germany?', The World Economy, 29, 5, 559-583

Greene, W. (2000), Econometric Analysis, Fourth Edition, Prentice Hall, New Jersey

Griliches, Z. and J. Hausman (1986), 'Errors in Variables in Panel Data', Journal of Econometrics, 31, 1, 93-118

Head, K. and J. Ries (2002), 'Offshore production and skill upgrading by Japanese manufacturing firms', Journal of International Economics, 58, 1, 81-105

Heathfield, D. and S. Wibe (1987), An Introduction to Cost and Production Functions, Humanities Press International, Atlantic Highlands, New Jersey 
Hijzen, A. (2005), 'A bird's eye view of international outsourcing: data, measurement and labour demand', Economie Internationale, 2005/4, 104, 45-63

Hijzen, A., H. Görg and R. Hine (2005), 'International outsourcing and the skill structure of labour demand in the United Kingdom', The Economic Journal, 115, 506, 860-878

Hsieh, C. and T. Woo (2005), 'The Impact of Outsourcing to China on Hong Kong's Labor Market', American Economic Review, 95, 5, 1673-1687

Kratena, K. (2010), International Outsourcing and the Demand for Skills', Empirica, 37, $65-85$

Michel, B. (2011a), 'Stock de capital par branche SUT 1995-2004', unpublished, internal document, Federal Planning Bureau, Brussels

Michel, B. (2011b), 'Productivity gains and spillovers from offshoring', Federal Planning Bureau, Working Paper 6-11, Brussels

Michel, B. and F. Rycx (2012), 'Does offshoring of materials and business services affect employment? Evidence for a small open economy', Applied Economics, 44, 2, 229251

Mion, G., H. Vandenbussche and L. Zhu (2010), ‘Trade with China and skill upgrading: evidence from Belgian firm level data', National Bank of Belgium, Working Paper Research, ${ }^{\circ} 194$, Brussels

Moulton, B. (1990), 'An illustration of a pitfall in estimating the effects of aggregate variables on micro units', The Review of Economics and Statistics, 72, 2, 334-338

OECD (2005), Science and Technology Scoreboard 2005, Paris

Schaffer, M. (2010), 'xtivreg2: Stata module to perform extended IV/2SLS, GMM and AC/HAC, LIML and k-class regression for panel data models' 
Strauss-Kahn, V. (2003), 'The role of globalisation in the within-industry shift away from unskilled workers in France’, NBER Working Paper n ${ }^{\circ} 9716$

Van den Cruyce, B. (2004), 'Use Tables for Imported Goods and Valuation Matrices for Trade Margins - an Integrated Approach for the Compilation of the Belgian 1995 Input-Output Tables', Economic Systems Research, 16, 1, 33-61

\section{Appendix}

Transcendental logarithmic ${ }^{38}$ or translog production and cost functions were introduced in the first half of the seventies in a number of papers, e.g. Christensen et al. (1971) and Berndt and Wood (1975), and have been frequently used in empirical work since then. They belong to the category of the so-called flexible functional forms that were developed in an attempt to impose as little a priori restrictions as possible. ${ }^{39}$ More precisely, translog cost functions allow substitution elasticities to be unrestricted - they must not even be constant - and they are nonhomothetic, meaning that cost-minimizing relative input demands may depend on the level of output ${ }^{40}$, hence allowing for U-shaped average cost functions.

Denoting total variable costs $C$, the prices of $N$ variable input factors $P_{j}$ and output $Y$, the general formulation of the translog cost function is as follows: ${ }^{41}$

$$
\ln C=\beta_{0}+\sum_{j=1}^{N} \beta_{j} \ln P_{j}+\frac{1}{2} \sum_{j=1}^{N} \sum_{k=1}^{N} \delta_{j k} \ln P_{j} \ln P_{k}+\beta_{Y} \ln Y+\frac{1}{2} \delta_{Y Y}(\ln Y)^{2}+\sum_{j=1}^{N} \delta_{j Y} \ln P_{j}(\text { A. } 1
$$

\footnotetext{
Transcendental means non-algebraic and a logarithmic function is one form of non-algebraic function. Another popular flexible functional form is the Generalised Leontief function.

40 Implying returns to scale of the dual production function are not constrained a priori, not even constant (see Berndt (1991), p.469-470)

41 For ease of presentation, time and industry subscripts have been omitted.
} 
In a classic KLEMS framework, equation (A.1) represents a five-factor model $(N=5)$, with capital $(\mathrm{K})$, labour $(\mathrm{L})$ and three intermediate inputs (energy $(\mathrm{E})$, materials (M) and services (S)) as variable factors of production. Labour can further be divided into different skill levels, augmenting the number of production factors $N$. It is standard to take into account capital as a quasi-fixed factor (at least in the short-run). In this case the number of variable input factors $N$ is reduced by one, capital costs are excluded from $C$, and capital enters the cost function in the same way as output.

In equation (A.1), $\frac{N(N-1)}{2}$ symmetry conditions $\left(\delta_{j k}=\delta_{k j}\right)$ can be imposed without loss of generality. Moreover, a 'well-behaved' cost function should be homogeneous of degree 1 in prices, meaning that a proportional increase in all variable input prices should shift total variable costs by the same proportion. This implies the following restrictions:

$$
\sum_{j=1}^{N} \beta_{j}=1 \quad ; \quad \sum_{j=1}^{N} \delta_{j k}=\sum_{k=1}^{N} \delta_{j k}=\sum_{j=1}^{N} \delta_{j Y}=0
$$

According to Shephard's lemma, the cost-minimizing input quantities $X_{j}$ can be derived by differentiating total costs with respect to the prices of the input factors:

$$
\frac{\partial C}{\partial P_{j}}=X_{j}
$$

Differentiating the translog cost function (A.1) with respect to input prices and applying Shephard's lemma (A.3), one obtains a set of $N$ cost share equations of the form:

$$
S_{j}=\beta_{j}+\sum_{k=1}^{N} \delta_{j k} \ln P_{k}+\delta_{j Y} \ln Y
$$


with the following adding-up condition:

$$
\sum_{j=1}^{N} S_{j}=\sum_{j=1}^{N} \frac{P_{j} X_{j}}{C}=1
$$

In the empirical literature, instead of estimating the translog cost function (A.1) directly, most authors estimate the system of cost share equations (A.4). ${ }^{42}$

As pointed out above, one attractive feature of flexible functional forms like translog cost functions is that they put no a priori restrictions on elasticities. The own price elasticities $\varepsilon_{j j}$ and cross price elasticities $\varepsilon_{j k}$, and the elasticities of substitution $\sigma_{j k}$ are given by the formulas below:

$$
\begin{aligned}
& \varepsilon_{j j}=\frac{\delta_{j j}}{S_{j}}-\left(1-S_{j}\right) \\
& \varepsilon_{j k}=\frac{\delta_{j k}}{S_{j}}+S_{k} \quad j \neq k \\
& \sigma_{j k}=\frac{\varepsilon_{j k}}{S_{k}}=\frac{\delta_{j k}}{S_{j} S_{k}}+1 \quad j \neq k
\end{aligned}
$$

These elasticities are not constant, but differ at every data point. It is common practice to compute them either at the means of the data, or for the first, central or last year of the sample. When computing estimates of these elasticities, fitted cost shares should be used rather than observed cost shares. ${ }^{43}$

42 This implies efficiency gains, notably because the number of parameters to be estimated is lower. It is also noteworthy that some authors, e.g. Baltagi and Rich (2005), simultaneously estimate the cost function and the system of cost share equations.

43 Then, given that the elasticities are nonlinear functions of the estimated parameters, the standard errors of the elasticities must be computed by the 'delta method'. This is done automatically by the command predictnl in Stata. 


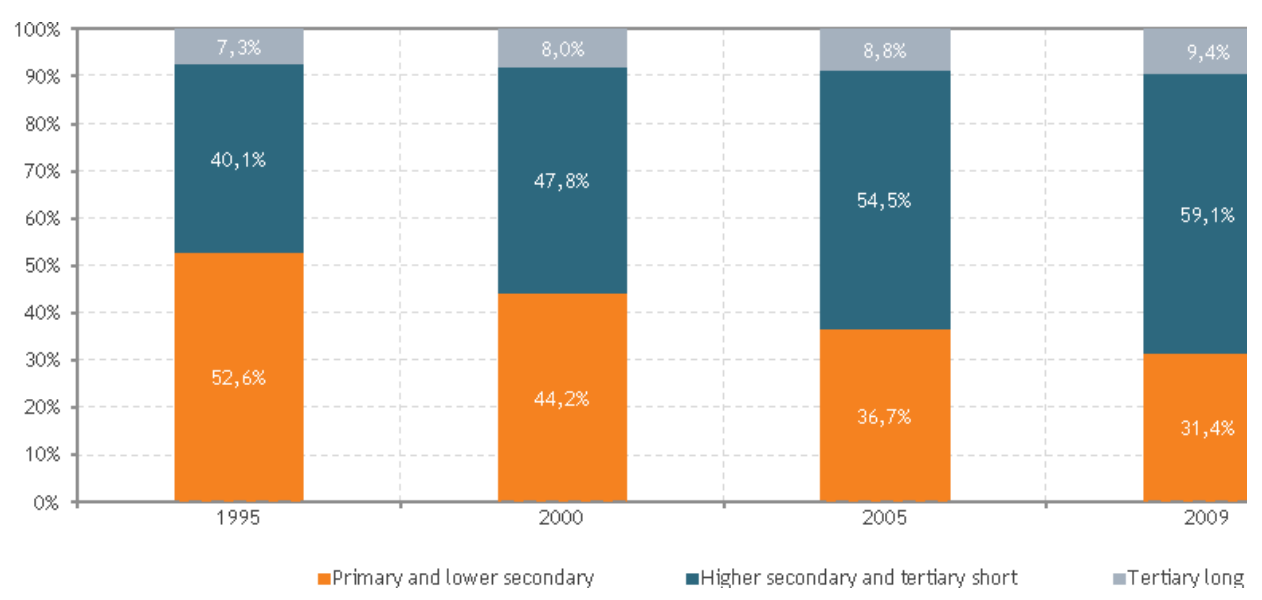

Source: own calculations based on FPB qualitative labour market data

Table 1 - Employment by skill level (1995-2009, growth rates)

\begin{tabular}{lccc}
\hline & & & \\
& $1995-2002$ & $2002-2009$ & $1995-2009$ \\
\hline Total & $-4 \%$ & $-7 \%$ & $-10 \%$ \\
Primary and lower secondary & $-26 \%$ & $-28 \%$ & $-46 \%$ \\
Higher secondary and tertiary short & $22 \%$ & $9 \%$ & $32 \%$ \\
Tertiary long & $10 \%$ & $5 \%$ & $15 \%$ \\
\hline
\end{tabular}

Source: own calculations based on FPB qualitative labour market data

Table 2 - Industry decomposition of the fall in the low-skilled employment share (1995-2007)

\begin{tabular}{lcc} 
& & \\
& Between industries & Within industries \\
\hline Change in low-skilled employment & $0.7 \%$ & $99.3 \%$ \\
\hline Source: own calculations based on FPB qualitative labour market data &
\end{tabular}


Table 3 Materials and business services offshoring, total and split by region of origin

\begin{tabular}{lcccccc}
\hline & \multicolumn{3}{c}{ Materials offshoring } & \multicolumn{3}{c}{ Business services offshoring } \\
& 1995 & 2007 & avg grt & 1995 & 2007 & avg grt \\
\hline Total & $35.68 \%$ & $38.33 \%$ & $0.6 \%$ & $0.71 \%$ & $1.94 \%$ & $8.7 \%$ \\
OECD & $32.57 \%$ & $32.13 \%$ & $-0.1 \%$ & $0.68 \%$ & $1.77 \%$ & $8.4 \%$ \\
CEEC & $0.55 \%$ & $1.95 \%$ & $11.2 \%$ & $0.02 \%$ & $0.06 \%$ & $11.9 \%$ \\
ASIA & $0.88 \%$ & $1.82 \%$ & $6.2 \%$ & $0.01 \%$ & $0.03 \%$ & $16.5 \%$ \\
\hline
\end{tabular}

Source: own calculations

Table 4 Average annual growth rates of current and constant price materials and business services offshoring over 1995-2007

\begin{tabular}{lcc}
\hline & Current prices & Constant prices \\
\hline Materials offshoring & $0.30 \%$ & $0.60 \%$ \\
Business services offshoring & $7.85 \%$ & $8.71 \%$ \\
\hline
\end{tabular}

Source: own calculations 
Table 5 Endogeneity tests for relative wage and materials and business services offshoring

\begin{tabular}{lccc} 
& In(relative wage) & Materials offshoring & Services offshoring \\
\hline Test stat $\left[x^{2}(1)\right]$ & 4.687 & 0.510 & 1.094 \\
p-value & 0.030 & 0.475 & 0.296 \\
\hline
\end{tabular}

Source: own calculations

Remarks: GMM distance test based on one-year and two-year lags of potentially endogenous regressor; clustered standard errors; HO: regressor can be treated as exogenous; computed with xtivreg2 (Schaffer, 2010) 


\section{Table 6 Estimation results with total offshoring intensities}

Dependent variable: low-skilled employment share

\begin{tabular}{|c|c|c|c|c|c|}
\hline & \multirow{2}{*}{$\begin{array}{l}\text { (a) } \\
\text { fe }\end{array}$} & \multirow{2}{*}{$\begin{array}{c}\text { (b) } \\
\text { 2sls }\end{array}$} & \multirow{2}{*}{$\begin{array}{c}\text { (c) } \\
\text { 2sls }\end{array}$} & \multirow{2}{*}{$\begin{array}{c}(d) \\
2 \text { sls }\end{array}$} & \multirow{2}{*}{$\begin{array}{c}(e) \\
\text { 2sls }\end{array}$} \\
\hline & & & & & \\
\hline \multirow[t]{2}{*}{ In(relative wage) } & -0.065 & $-0.278^{\star \star *}$ & $-0.292^{\star * \star}$ & $-0.276^{\star * *}$ & $-0.285^{\star * *}$ \\
\hline & $(0.107)$ & $(0.065)$ & $(0.068)$ & $(0.062)$ & $(0.068)$ \\
\hline \multirow[t]{2}{*}{ In(value added) } & 0.000 & -0.006 & -0.006 & -0.000 & 0.015 \\
\hline & $(0.019)$ & $(0.017)$ & $(0.017)$ & $(0.015)$ & $(0.014)$ \\
\hline \multirow[t]{2}{*}{ In(non-ICT capital stock) } & $-0.190^{\star \star \star}$ & $-0.188^{\star \star *}$ & $-0.195^{\star \star *}$ & $-0.167^{\star * \star}$ & $-0.169^{* \star *}$ \\
\hline & $(0.043)$ & $(0.045)$ & $(0.046)$ & $(0.042)$ & $(0.043)$ \\
\hline \multirow[t]{2}{*}{ In(ICT capital stock) } & 0.002 & -0.005 & -0.004 & -0.006 & $-0.037^{\star *}$ \\
\hline & $(0.024)$ & $(0.021)$ & $(0.021)$ & $(0.019)$ & $(0.018)$ \\
\hline \multirow[t]{2}{*}{$R \& D$-intensity } & -0.078 & -0.212 & -0.230 & -0.160 & -0.145 \\
\hline & $(0.114)$ & $(0.133)$ & $(0.146)$ & $(0.126)$ & $(0.125)$ \\
\hline \multirow[t]{2}{*}{ Materials offshoring } & $-0.180^{* *}$ & $-0.143^{\star *}$ & & $-0.234^{* * *}$ & $-0.192^{\star \star *}$ \\
\hline & $(0.082)$ & $(0.068)$ & & $(0.071)$ & $(0.066)$ \\
\hline \multirow[t]{2}{*}{ Services offshoring } & $-1.763^{\star \star *}$ & $-1.531^{* \star *}$ & & $-2.093^{\star \star *}$ & $-1.544^{\star * *}$ \\
\hline & $(0.454)$ & $(0.370)$ & & $(0.495)$ & $(0.484)$ \\
\hline \multirow[t]{2}{*}{ Materials offshoring (current prices) } & & & -0.087 & & \\
\hline & & & $(0.071)$ & & \\
\hline \multirow[t]{2}{*}{ Services offshoring (current prices) } & & & $-1.398^{\star \star *}$ & & \\
\hline & & & $(0.337)$ & & \\
\hline \multirow[t]{2}{*}{ Hitech * Materials offshoring } & & & & $0.292^{\star *}$ & \\
\hline & & & & $(0.115)$ & \\
\hline \multirow[t]{2}{*}{ Hitech * Services offshoring } & & & & $1.045^{\star}$ & \\
\hline & & & & $(0.549)$ & \\
\hline \multirow[t]{2}{*}{ ICTcapital intensity * Materials offshoring } & & & & & $0.263^{\star \star *}$ \\
\hline & & & & & $(0.058)$ \\
\hline \multirow[t]{2}{*}{ ICTcapital intensity * Services offshoring } & & & & & 0.211 \\
\hline & & & & & $(0.293)$ \\
\hline Observations & 819 & 693 & 693 & 693 & 693 \\
\hline R-squared & 0.447 & 0.424 & 0.387 & 0.463 & 0.454 \\
\hline Number of nace_num & 63 & 63 & 63 & 63 & 63 \\
\hline Hansen $J$ stat $\left[\chi^{2}(1)\right]$ & & 3.136 & 3.511 & 2.333 & 2.538 \\
\hline$p$-value & & {$[0.077]$} & {$[0.061]$} & {$[0.127]$} & [0.111] \\
\hline Underidentification test ( $p$-value) & & {$[0.006]$} & {$[0.006]$} & {$[0.006]$} & {$[0.006]$} \\
\hline Weak identification test (F-stat) & & 5594 & 6332 & 3850 & 5240 \\
\hline
\end{tabular}

Source: own calculations

Remarks: 63 manufacturing industries covered; HAC standard errors with correction for clustering reported in parentheses; fe: fixed effects; 2sls: two-stage least squares (fe estimations in both stages, estimations with xtivreg2 module in stata (Schaffer, 2010)); Hansen J stat and p-value: test of validity of over-identifying restrictions $\left(\mathrm{H}_{0}\right.$ : overidentifying restrictions valid); reported significance levels: ${ }^{*} \mathrm{p}<0.1,{ }^{* *} \mathrm{p}<0.05,{ }^{* * *} \mathrm{p}<0.01$. 
Table 7 Endogeneity tests for regional materials offshoring intensities

\begin{tabular}{lcccc}
\hline & $\begin{array}{c}\text { Materials offshoring } \\
\text { to OECD }\end{array}$ & $\begin{array}{c}\text { Materials offshoring } \\
\text { to CEEC }\end{array}$ & $\begin{array}{c}\text { Materials offshoring } \\
\text { to ASIA }\end{array}$ & $\begin{array}{c}\text { Materials offshoring } \\
\text { to OTHER }\end{array}$ \\
\hline Test stat $\left[x^{2}(1)\right]$ & 0.864 & 0.517 & 0.769 & 0.020 \\
p-value & 0.353 & 0.472 & 0.380 & 0.888 \\
\hline
\end{tabular}

Source: own calculations

Remarks: GMM distance test based on one-year and two-year lags of potentially endogenous regressor; clustered standard errors; H0: regressor can be treated as exogenous; computed with xtivreg2 (Schaffer, 2010).

\section{Table 8 Estimation results with regional materials offshoring intensities}

Dependent variable: low-skilled employment share

\begin{tabular}{|c|c|c|c|}
\hline & $\begin{array}{l}\text { (a) } \\
\text { fe }\end{array}$ & $\begin{array}{c}\text { (b) } \\
\text { 2sls }\end{array}$ & $\begin{array}{c}\text { (c) } \\
\text { gmm }\end{array}$ \\
\hline In(relative wage) & $\begin{array}{l}-0.099 \\
(0.098)\end{array}$ & $\begin{array}{c}-0.268^{* * *} \\
(0.057)\end{array}$ & $\begin{array}{c}-0.250^{\star * *} \\
(0.053)\end{array}$ \\
\hline In(value added) & $\begin{array}{l}-0.011 \\
(0.016)\end{array}$ & $\begin{array}{l}-0.019 \\
(0.014)\end{array}$ & $\begin{array}{l}-0.016 \\
(0.014)\end{array}$ \\
\hline In(non-ICT capital stock) & $\begin{array}{c}-0.134^{* * *} \\
(0.039)\end{array}$ & $\begin{array}{c}-0.132^{\star \star \star} \\
(0.044)\end{array}$ & $\begin{array}{c}-0.149^{\star \star \star} \\
(0.040)\end{array}$ \\
\hline In(ICT capital stock) & $\begin{array}{c}0.006 \\
(0.020)\end{array}$ & $\begin{array}{c}0.003 \\
(0.018)\end{array}$ & $\begin{array}{l}-0.003 \\
(0.017)\end{array}$ \\
\hline R\&D-intensity & $\begin{array}{l}-0.108 \\
(0.084)\end{array}$ & $\begin{array}{c}-0.092 \\
(0.072)\end{array}$ & $\begin{array}{c}-0.093 \\
(0.072)\end{array}$ \\
\hline Materials offshoring to OECD & $\begin{array}{l}-0.028 \\
(0.078)\end{array}$ & $\begin{array}{c}0.013 \\
(0.064)\end{array}$ & $\begin{array}{c}0.022 \\
(0.063)\end{array}$ \\
\hline Materials offshoring to CEEC & $\begin{array}{c}-3.354^{\star * *} \\
(0.659)\end{array}$ & $\begin{array}{c}-2.828^{\star * *} \\
(0.581)\end{array}$ & $\begin{array}{c}-2.586^{\star \star *} \\
(0.509)\end{array}$ \\
\hline Materials offshoring to ASIA & $\begin{array}{c}-0.485^{\star \star} \\
(0.213)\end{array}$ & $\begin{array}{c}-0.422^{\star *} \\
(0.194)\end{array}$ & $\begin{array}{c}-0.417^{\star \star} \\
(0.194)\end{array}$ \\
\hline Materials offshoring to OTHER & $\begin{array}{l}-0.765 \\
(0.464)\end{array}$ & $\begin{array}{l}-0.886^{*} \\
(0.485)\end{array}$ & $\begin{array}{l}-0.777^{*} \\
(0.468)\end{array}$ \\
\hline Services offshoring & $\begin{array}{c}-1.386^{\star \star *} \\
(0.362)\end{array}$ & $\begin{array}{c}-1.195^{\star \star \star} \\
(0.282)\end{array}$ & $\begin{array}{c}-1.228^{\star \star \star} \\
(0.279)\end{array}$ \\
\hline Observations & 819 & 693 & 693 \\
\hline R-squared & 0.632 & 0.614 & 0.610 \\
\hline Number of nace_num & 63 & 63 & 63 \\
\hline Hansen $J$ stat $\left[\chi^{2}(1)\right]$ & . & 0.749 & 0.749 \\
\hline$p$-value & . & 0.387 & 0.387 \\
\hline
\end{tabular}


Source: own calculations

Remarks: 63 manufacturing industries covered; HAC standard errors with correction for clustering reported in parentheses; fe: fixed effects; 2sls: two-stage least squares; gmm: generalised method of moments (estimations with xtivreg2 module in stata (Schaffer, 2010)); Hansen $\mathrm{J}$ stat and $\mathrm{p}$-value: test of validity of over-identifying restrictions $\left(H_{0}\right.$ : overidentifying restrictions valid); reported significance levels: ${ }^{*} p<0.1,{ }^{* *} p<0.05,{ }^{* \star *} p<0.01$.

\section{Table A1 List of manufacturing industries, sUT-code and description}

$14 \mathrm{~A}$ Mining and quarrying of stone, sand, clay and chemical and fertilizer materials, production of salt, and other mining and quarrying n.e.c.

$15 \mathrm{~A}$ Production, processing and preserving of meat and meat products

15B Processing and preserving of fish and fish products

15C Processing and preserving of fruit and vegetables

15D Manufacture of vegetable and animal oils and fats

15E Manufacture of dairy products

$15 \mathrm{~F}$ Manufacture of grain mill products, starches and starch products

15G Manufacture of prepared animal feeds

$15 \mathrm{H}$ Manufacture of bread, fresh pastry goods, rusks and biscuits

15I Manufacture of sugar, chocolate and sugar confectionery

15J Manufacture of noodles and similar farinaceous products, processing of tea, coffee and food products n.e.c.

15K Manufacture of beverages except mineral waters and soft drinks

$15 \mathrm{~L}$ Production of mineral waters and soft drinks

16A Manufacture of tobacco products

17A Preparation and spinning of textile fibres, weaving and finishing of textiles

17B Manufacture of made-up textile articles, except apparel, other textiles, and knitted and crocheted fabrics

18A Manufacture of wearing apparel; dressing and dyeing of fur

19A Tanning and dressing of leather; manufacture of luggage, handbags, saddlery, harness and footwear

20A Manufacture of wood and of products of wood and cork, except furniture; manufacture of articles of straw

21A Manufacture of pulp, paper and paper products

22A Publishing

22B Printing and service activities related to printing, reproduction of recorded media

23A Manufacture of coke, refined petroleum products and nuclear fuel

24A Manufacture of basic chemicals

24B Manufacture of pesticides and other agro-chemical products

24C Manufacture of paints, varnishes and similar coatings, printing ink and mastics

24D Manufacture of pharmaceuticals, medicinal chemicals and botanical products

24E Manufacture of soap and detergents, cleaning and polishing preparations, perfumes and toilet preparations

$24 \mathrm{~F}$ Manufacture of other chemical products

24G Manufacture of man-made fibres

25A Manufacture of rubber products

25B Manufacture of plastic products

26A Manufacture of glass and glass products

26B Manufacture of ceramic products

26C Manufacture of cement, lime and plaster

26D Manufacture of articles of concrete, plaster and cement; cutting, shaping and finishing of stone; manufacture of other non-metallic mineral products

27A Manufacture of basic iron and steel and of ferro-alloys and tubes 
27B Other first processing of iron and steel; manufacture of non-ferrous metals; casting of metals

28A Manufacture of structural metal products, tanks, reservoirs, containers of metal, central heating radiators, boilers and steam generators; forging, pressing, stamping and roll forming of metal

28B Treatment and coating of metals; general mechanical engineering

28C Manufacture of cutlery, tools, general hardware and other fabricated metal products

29A Manufacture of machinery for the production and use of mechanical power, except aircraft and vehicle engines

29B Manufacture of other general purpose machinery

29C Manufacture of agricultural and forestry machinery and of machine tools

29D Manufacture of domestic appliances

$30 \mathrm{~A}$ Manufacture of office machinery and computers

31A Manufacture of electric motors, generators and transformers, of electricity distribution and control apparatus, and of insulated wire and cable

31B Manufacture of accumulators, batteries, lamps, lighting equipment and electrical equipment

32A Manufacture of radio, television and communication equipment and apparatus

33A Manufacture of medical, precision and optical instruments, watches and clocks

34A Manufacture of motor vehicles

34B Manufacture of bodies (coachwork) for motor vehicles, of trailers and parts and accessories for motor vehicles

$35 \mathrm{~A}$ Building and repairing of ships and boats; manufacture of locomotives and rolling stock, and of aircraft

35B Manufacture of motorcycles and bicycles and other transport equipment n.e.c.

$36 \mathrm{~A}$ Manufacture of furniture

36B Manufacture of jewellery and related articles

36C Manufacture of musical instruments, sports goods, games and toys; miscellaneous manufacturing

37A Recycling

45A Site preparation

45B General construction of buildings and civil engineer works; erection of roof covering and frames

45C Construction of motorways, roads, airfields, sports facilities and water projects; other construction work

45D Building installation

45E Building completion; renting of construction or demolition equipment with operator 


\section{Table A2 Data sources}

\begin{tabular}{|c|c|c|c|c|}
\hline Variable & Name & Data source & Splits & References \\
\hline Y & Output & $\begin{array}{l}\text { Harmonised SUT }\left(\mathrm{FPB}^{1}\right) \\
\text { based on data from } \mathrm{NAI}^{2}\end{array}$ & & Avonds et al. (2012) \\
\hline VA & Value added & $\begin{array}{l}\text { Harmonised SUT }\left(\mathrm{FPB}^{1}\right) \\
\text { based on data from } \mathrm{NAI}^{2}\end{array}$ & & Avonds et al. (2012) \\
\hline IIM, IIS & Intermediates & $\begin{array}{l}\text { Harmonised SUT }\left(\mathrm{FPB}^{1}\right) \\
\text { based on data from } \mathrm{NAI}^{2}\end{array}$ & $\begin{array}{l}\text { Imported (by region } \\
\text { based on detailed trade } \\
\text { data from } \mathrm{NBB}^{3} \text { ) }\end{array}$ & $\begin{array}{l}\text { Van den Cruyce (2004), } \\
\text { Avonds et al. (2012), } \\
\text { Michel and Rycx (2012) }\end{array}$ \\
\hline $\mathrm{K}$ & Capital stock & $\begin{array}{l}\text { Own calculations based on } \\
\text { detailed investment data } \\
\text { from } \mathrm{NBB}^{3}\end{array}$ & ICT and non-ICT & $\begin{array}{l}\text { Biatour et al. (2007), } \\
\text { Michel (2011a) }\end{array}$ \\
\hline $\mathrm{L}$ & $\begin{array}{l}\text { Labour } \\
\text { (number of workers) }\end{array}$ & $\begin{array}{l}\text { Social Accounting matrix } \\
\left(\mathrm{SAM}-\mathrm{FPB}^{1}\right) \text { based on } \\
\mathrm{NAI}^{2} \text { data }\end{array}$ & By level of education & Bresseleers et al. (2007) \\
\hline W & Labour compensation & $\begin{array}{l}\text { Own calculation based } \\
\text { harmonised SUT }\left(\mathrm{FPB}^{1}\right) \text { and } \\
\text { on } \mathrm{NAI}^{2} \text { data }\end{array}$ & By level of education & $\begin{array}{l}\text { Avonds et al. (2012), } \\
\text { Dumont (2008) }\end{array}$ \\
\hline$R \& D$ & $R \& D$ stock & $\begin{array}{l}\text { Own calculations based on } \\
R \& D \text { expenditure data from } \\
B S P^{4}\end{array}$ & & $\begin{array}{l}\text { Biatour, Dumont and } \\
\text { Kegels (2011) }\end{array}$ \\
\hline
\end{tabular}

Remarks: 1 Federal Planning Bureau

2 National Accounts Institute

3 National Bank of Belgium

4 Belgian Science Policy (belspo)

Table A3 Descriptive statistics

\begin{tabular}{lrrrr}
\hline & 1995 & 2007 & abs change & avg grt \\
\hline & & & & $-3.6 \%$ \\
Low-skilled employment share & 0.53 & 0.34 & -0.19 & $0.2 \%$ \\
Relative wage of low-skilled & 0.73 & 0.74 & 0.01 & $1.6 \%$ \\
Value added (bn of $2005 €$ ) & 51.72 & 62.68 & 10.96 & $2.1 \%$ \\
ICT capital (bn of $2005 €$ ) & 5.48 & 7.03 & 1.55 &
\end{tabular}


Source: see Table A2; own calculations

\section{Table A4 GMM estimation results with total offshoring intensities}

Dependent variable: low-skilled employment share

\begin{tabular}{|c|c|c|c|}
\hline $\begin{array}{c}\text { (a) } \\
\text { gmm }\end{array}$ & $\begin{array}{c}\text { (b) } \\
\text { gmm }\end{array}$ & $\begin{array}{c}\text { (c) } \\
\text { gmm }\end{array}$ & $\begin{array}{c}\text { (d) } \\
\text { gmm }\end{array}$ \\
\hline$-0.233^{* * *}$ & $-0.239^{* \star *}$ & $-0.237^{\star \star \star}$ & $-0.230^{* * *}$ \\
\hline$(0.060)$ & $(0.062)$ & $(0.057)$ & $(0.059)$ \\
\hline 0.001 & -0.001 & 0.006 & 0.003 \\
\hline$(0.016)$ & $(0.017)$ & $(0.014)$ & $(0.015)$ \\
\hline$-0.215^{\star \star \star}$ & $-0.227^{\star \star \star}$ & $-0.189^{\star * *}$ & $-0.211^{\star \star *}$ \\
\hline$(0.042)$ & $(0.043)$ & $(0.040)$ & $(0.042)$ \\
\hline-0.012 & -0.009 & -0.010 & -0.029 \\
\hline$(0.021)$ & $(0.020)$ & $(0.019)$ & $(0.025)$ \\
\hline-0.218 & -0.238 & -0.146 & -0.192 \\
\hline$(0.133)$ & $(0.146)$ & $(0.126)$ & $(0.141)$ \\
\hline$-0.140^{\star *}$ & & $-0.221^{* \star *}$ & -0.267 \\
\hline$(0.068)$ & & $(0.071)$ & $(0.179)$ \\
\hline$-1.652^{\star \star *}$ & & $-2.032^{\star \star *}$ & $-2.704^{\star * *}$ \\
\hline \multirow[t]{13}{*}{$(0.363)$} & & $(0.493)$ & $(0.584)$ \\
\hline & -0.083 & & \\
\hline & $(0.071)$ & & \\
\hline & $-1.542^{\star \star \star}$ & & \\
\hline & $(0.328)$ & & \\
\hline & & $0.292^{\star *}$ & \\
\hline & & $(0.115)$ & \\
\hline & & 0.854 & \\
\hline & & $(0.535)$ & \\
\hline & & & 0.041 \\
\hline & & & $(0.052)$ \\
\hline & & & $0.243^{\star \star *}$ \\
\hline & & & $(0.084)$ \\
\hline
\end{tabular}

Observations

$\begin{array}{cccc}693 & 693 & 693 & 693 \\ 0.418 & 0.380 & 0.459 & 0.431\end{array}$


Number of nace_num

Hansen J stat

p-value
63

3.136

63

3.511

[0.061]
63

2.333

[0.127]
63

3.000

[0.083]

Remarks: 63 manufacturing industries covered; standard errors with correction for clustering reported in parentheses; gmm: generalised method of moments (estimations with xtivreg2 module in stata (Schaffer, 2010)); Hansen J stat and $p$-value: test of validity of over-identifying restrictions $\left(\mathrm{H}_{0}\right.$ : overidentifying restrictions valid); reported significance levels: * $p<0.1,{ }^{* *} p<0.05,{ }^{* * *} p<0.01$.

Table A5 Own-price elasticities for low-skilled and high-skilled workers for estimations with total offshoring intensities

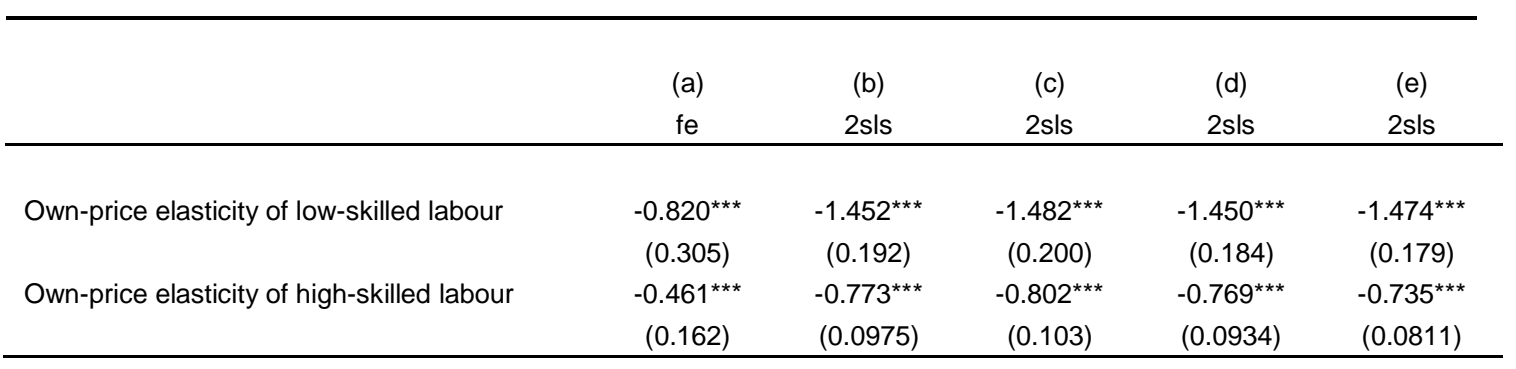

Source: own calculations

Remarks: elasticities computed according to equation (5) based on estimates of $\delta_{\|}$in Table 6 and fitted values for 2007; standard errors in parentheses calculated with delta method; columns correspond to those in Table 6; reported significance levels: ${ }^{*} p<0.1,{ }^{* *} p<0.05,{ }^{* * *} p<0.01$. 